\title{
Significance of Inlay Work in the Modern Mosque at Islamabad
}

\author{
Dr. Samina Nasim \\ Institute of Design and Visual Arts, Lahore College for Women University Lahore, Pakistan
}

\begin{abstract}
This research papergives a comprehensive study of the structural forms, decorative designsand inlay work of themihrāb, marble fountain and kursi built in the sanctuary of the Faisal MosqueIslamabad. At first inlay work with lapis lazuli on themihräbof the mosque is mentioned. Secondly golden metallic inlay decoration of the walls and floor of the marble fountain is explained and lastly the technique is discussed with the reference to the kursi built in the sanctuary of the mosque.The technique is discussed along with knowledge of their historical applications in mosques throughout the Islamic world. The rich selection of geometric designs for these elements is described. Picture and drawings are by the author. The study is accompanied by one picture and six drawings.
\end{abstract}

Keywords: Fountain, Geometrical Design, Lapislazuli,Mihräb,Modern Architecture,Mughal, Stylized Design.

\section{Introduction}

Since ages, architectural decoration is considered as integral part of building to cover the plain and opensurface of constructive elements of interior and exterior. In South Asia especially in Mughal period this technique was lavishly adopted for the surface decoration of their monuments and become famous among their contemporaries.For 100 years no inlay decoration has found in the religious buildings of Punjab Pakistan. But in modern times advance form of inlay work has been found in Faisal Mosque Islamabad. Several scholars have offered comments on thismodern religious building of Pakistan.This literature is very limited and gives little information about the exterior design elevation of the structure and brief knowledge of its design elements. But they do not mention anything about thetechniques, structural and surface decoration of the building.From the brief review of the existing literature, it is apparent thatits inlay work has never been examined closely or comprehensively studied. Researchers and scholars have concentrate on only basic information of the building. They give only a cursory statement about the mosque. Nobody has discussed inlay decoration and its aesthetic value. The aesthetic limitations of inly work the functional relationships advancement of the technique, and a study of the design patterns, all still awaited examination. Due to this lack of study and research the significance of thetechnique in this mosque does not have the status in South Asia which it deserves.

The purpose of the present research is to discuss the inlay decoration of the Faisal Mosque from an aesthetics point of view. By comparing the past with the present, I mean to point out the modernity of the technique practically used in this mosque, and the various ways in which the past traditional designs of the Islamic world have been stylized.

\section{Inlay work on themihrābof the Faisal Mosque}

The Faisal Mosque Islamabad completedin 1988 has a highly unusual freestanding mihrāb in the form of an open Qur'ān made of Thassos marble.Its central part is decorated with the name of "Allah" is inlaid in marble with semi-precious stone lapis lazuli in flat manner"Fig. 1".The name is inlaid in muthanna style.

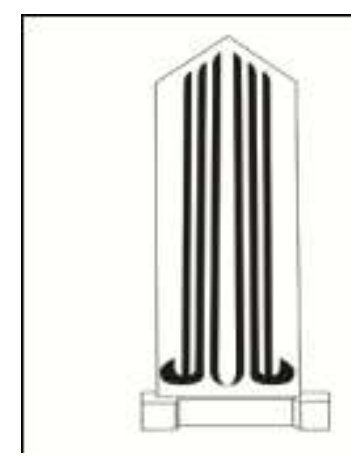

Fig1. The name of Allah in muthanna style inlaid on the central part of the mihrāb in the Faisal Mosque.

In twelfth and thirteenth century Saljuq architectural forms were developed in Iraq and Syria. These trends of decoration were continued in Syria and Egypt with the use of polychrome stone inlay on plain walls 
derived from Saljuqs of Anatolia andwas handed down by the Ayyubids to generations of architects both in Syria and Egypt [1].

The use of the intensely blue stone lapis lazuli for inlay work dates from ancient times. The Egyptians, Sumerians and Greeks inlaid lapis lazuli in collage paintings and sculptural decorations and also used it as a painting pigment.

The first inlay was used on the Harp of Queen Shuhab at Ur in (2688 B.C). The instrument was inlaid with lapis lazuli, as well as shell, strips of gold and red limestone [2]. In the same period, some famous paintings were discovered in which small pieces of leather, lapis lazuli, gold, sea shells and a variety of precious and semi precious stones were inlaid. Tancsey and Kleiner write that in Sumerian Art, a rectangular wooden box with sloping sides inlaid with shell, lapis lazuli, and red limestone was excavated at Ur and dates to 2700 B.C. A portrait of a Queen from Gurob of the eighteenth Dynasty (c1355-1335 B.C.) has her eyes inlaid in glass and earrings made of gold and lapis lazuli. The coffin of Tutankhamen, from his tomb at Thebes, eighteenth Dynasty (c.1325 B.C) and the death mask of Tutankhamen both were made of gold with inlay of semi-precious stones including lapis lazuli. All flat surfaces of the late Gothic art in Italy were inlaid with gold, lapis lazuli, mosaic and cut marble in geometric patterns termed as "cosmato work". Trend of the use of lapis lazuli for decorative purpose was continued and adopted by Muslims[3].

Inlay work with delicate setting of precious and semiprecious stones began in South Asia before the arrival of Mughals. But it flourished highly during the Mughal period in the seventeenth century. The Mughal artists covered entire surface of wall with inlay (pietra dura) decorations. In the Faisal Mosque careful and neat finishing of flat inlay in lapis lazuli reveals artistic merit and gives a colour to the white and golden of themihrāb. The inlay work has been achieved with the help of latest technology and equipment for drilling. Bladed electric rods and electric grinders were used to complete the metallic strips and lapis lazuli inlay in white marble. The King Faisal Foundation Mosque, Riyadh Saudi Arabia, completed in 1982, is the one of the twentieth century mosque whose interior was embellished withlapis lazuli [4].

An artistic and aesthetic effect of themihräbof the Faisal Mosque is obtained by its elevation, proportionate and the symmetry. Its colour scheme of gold, white and blue is aesthetically pleasing.

\section{Golden metallic inlay on marble fountain}

At the eastern side of the sanctuary close to the eastern entrance there is a large fountain rectangular in plan with chamfered corners"Fig. 2". The fountain is only built for decoration not as an auxiliary ablution area. It is raised two steps up from the first level of the sanctuary's floor. Every step is five and a half inch high. Entrance to the fountain area is by steps at the chamfered corners. Pair of book is built at four corners of the fountain, and again suggest similarity to the open book shapes noted throughout the Faisal Mosque. Every book is two feet nine inches high and one foot eleven inches wide.

Low walls of marble surround the fountain. The marble walls are two feet two inches high. The northern and southern walls are eleven inches thick and forty-three feet long; and the eastern and western walls are forty-six feet long. The fountain is entirely constructed in white Thassos marble inlaid with golden metallic strips "Fig. 3". The inlay work of its low walls stands in slight relief. These golden metallic stripes are four sixteenth of an inch wide, and three sixteenth of an inch above the surface and are embedded in the marble four sixteenth of an inch, its sculptural form is prominent. The four outer walls of the fountain have fifty-two matching linear compositions, twenty-four on the east and west side and twenty-eight on north and south sides. The designs are two feet two inches high and one foot wide. For the inlay, strips of the required size are cut and slightly hammered into four sixteenth of an inch deep prepared groves and finally, the surface is burnished.

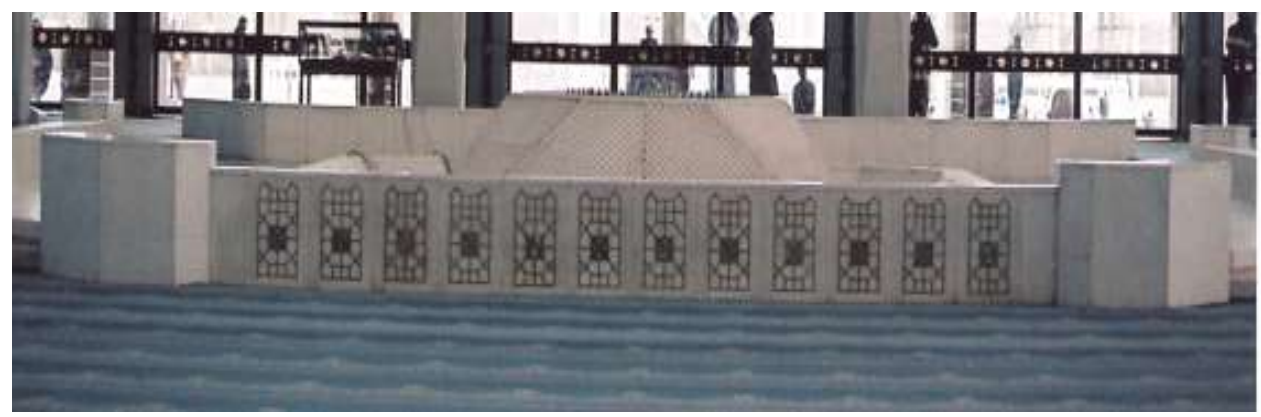

Fig . 2. Fountain with twelve individual linear compositions on the low walls, seen from the west. 


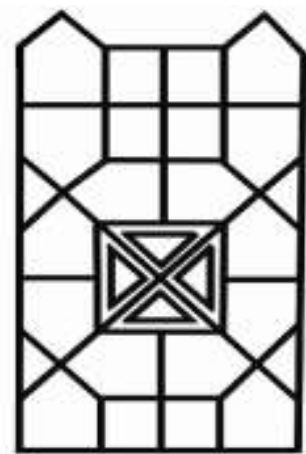

Fig 3. Inlaid design in relief on the low wallsof the fountain in the sanctuary of the Faisal Mosque.

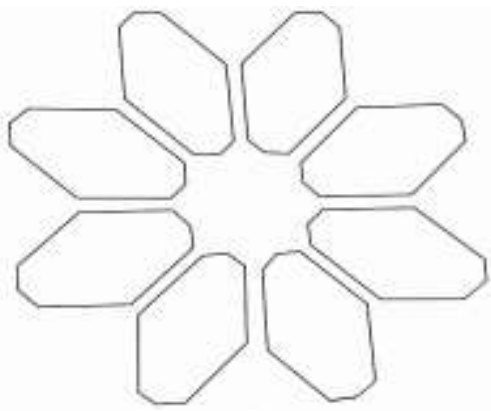

Fig 4. Inlaid flowers on the floor of the marble fountain.

The floor of the fountain area also has golden metal inlay work in white marble, flush with the surface in a flat manner. The floor area is eight feet on all sides. It has octagonal stars and floral pattern of eight petals, composed with all straight lines "Fig. 4". Its linear geometrical designs are leveled with surface instead of in relief. Four sixteenth of an inch broad golden metallicstrips are inlaid for decoration.Each petal has eight straight lines and eight corners. The distance between every petal is two inches and one eighth of an inch in width. The size of every petal is two feet in length and one foot five inches wide and the center void takes on the shape of an eight-pointed star one foot eleven inches in diameter. The total "flower" is six feet in diameter. There are eight inlaid flowers on the floor of the fountain. Straight lines where the white marble tiles are joined are not prominent but are clearly visible on the white surface. These lines make a network of square, rectangular and triangular shapes.

The inlay work of the fountain floor has neat finish. But the contrast of the patterns with the joining of the marble tiles does not give a harmonious design. The fountain is entirely built of marble with inlay work with the marble carving adorning its surface. It gives a peaceful and sober impression of white and royalty of golden colour.

After entering into the sanctuary through the eastern doors, the marble fountain with its unusual design and decoration is the first attraction. Fountains are sometimes found within the sanctuary of Ottoman mosques.An octagonal shape fountain formally used for ablution is placed within the Yesil Mosque, Bursa, built in 1412-1419 [5]. The interior of the Salimi Mosque, Edirne, built in 1569-1575 has a fountain in the sanctuary under the mu'adhdhin pew [6].

Several examples of inlay work of stone and tiles can be found in Islamic art. But inlay decoration with metal on marble with stylized designs is new for the South Asia. During the Ayubid period polychrome stone inlay on plain walls was derived from Saljuq Anatolia and handed down by the Ayubids to generations of architects both in Syria and Egypt [7].Inlay work was a part of Mamlūk architectural decoration especially for mihrāband other places of special importance [8]. The Mamlūks used coloured glass mosaic and inlaid marble formihrābbut ceramic tile decoration was rare. "After the fourteenth century tile-mosaic and marble inlay allow for thinness of line, subtle colour combinations, and sudden shifts of emphasis from one inscription to another. The mastery of the inlaid mosaic technique allowed calligraphers to display their skill on a very large scale ..." [9].In Muslim history especially in Turkey, Iran and India inlay was used as a very posh decorative technique. Inlay decoration of the AshrafiMahal at Mandu (India), constructed about 1450 during the Khilji dynasty, is a great example of the use of inlay decoration before the Mughals [10]. The Qila'-i-Kahna Mosque at Delhi, built in 1541, is another example of the use of coloured marble (white, black and yellow) fixed with red sand stone both in tessellated and inlaid patterns [11].

During the Mughal period, inlay created the effect of richness with the help of bright attractive colours and complexity of designs. The tomb of Humayun, begun around 1565, the tomb of Akbar at Sikandra, India, 
Significance of Inlay Work in the Modern Mosque at Islamabad

Jahangiri Mahal, Agra Fort, and the Jami ' Masjid of Fatehpur Sikri, tomb of Itmad-ud-Daulah (built in 1622) are out-standing examples of inlay work [12].During the reign of Emperor Shahjahan, monuments were decorated with rich and marvelous decorative techniques. Inlay art flourished during this period. The style of inlay decoration for buildings was very minute. R. Nath writes that stylized floral designs were executed with tiny pieces of precious and semi-precious stones [13].The Shahjahan`s Mosque in Delhi has wide inlaid work with inscriptions in black marble [14].In the Jahan Ara Mosque, Agra, built in 1648, the bulbous dome is inlaid with wide bands of alternating red sand stone and marble [15].The Taj Mahal, Agra, built in 1631-1648, the Jami ' Masjid, Delhi, built in 1644, the Shahjahan Mosque, Thatta, built in 1644, Moti Masjid, Lahore, built in 1659-1660, and the Badshahi Mosque, Lahore, built in 1673 are paragons of this decorative mode. In the BadshahiMosque, inlaid work on flat surface and in low relief have been executed with perfect technique; decorative floral motifs were cut out of white marble and inlaid on red stone in flat and embossed manner. Ahmad Nabi Khan writes about the floral ornamentation of Badshahi Mosque and says that it has bold relief inlay of white marble on red sand stone background on its entire exterior [16].

During the Mughal period, pavilions were profusely decorated with the inlay work of coloured stones representing beautiful flowers vases, trees, cypress and geometrical designs. In this period colourful precious and semi precious stones are inlaid into white marble, which is called parchinkari. During Shahjahan's reign, marble was preferred instead of red sand stone. The art of Florence in Italy of the late sixteenth century influenced the inlay of Shahjahan buildings, so Italian influence can be found in the Mughal's pietra dura work[17].In the Diwan-i Am of Delhi Fort, plaques of grayish black Indian marble are inlaid with designs based on Italian birds and foliage [18].

The mosques of the Mughal period have fabulous and exclusive examples of inlay work in naturalistic style with the intermingling of geometrical framing designs. The Badshahi Mosque Lahore is the most prominent example of the combination of delicate carving and inlay work of white marble in red sand stone. Inlay work continues in modern times, for the surface decorations of mosques.

After the Mughals the technique was not maintained. The standards for such decoration was reduced in practice and gradually declined. As a result the newly built modern mosques of the twentieth century are free from inlay decoration. A single mosque of Punjab (Pakistan) has not been decorated with inlay work since the 1980s.

In the Faisal Mosque the technique is revived and while we can say that the inlay work of the Faisal Mosque is a revival of the Mughal tradition of inlay work it is not similar to Mughal style. The Mughals inlaid precious or semi-precious stones in marble but in the Faisal Mosque metal is inlaid in marble on the walls and floor of the fountain. The technique is similar to that of the Mughals, but the material and aesthetics are different. The inlay work on the walls of the fountain in the sanctuary of the Faisal Mosque breaks the monotonous effect of flat white marble surface of the walls and the floor. Both relief and flat inlay of geometrical designs of the fountain have their own importance. All the designs, and their cutting, fixing and engraving are well finished. In contrast to the inlay work of the Faisal Mosque, the inlaying of coloured stone in white marble during the Shahjahan period was of a higher quality. Its application, selection of designs, colourful birds, flower, stems and leaves variety of coloured stones--and perfection in finishing all goes with the luxurious nature of the Mughals. In the Faisal Mosque simple straight lines inlaid in white marble represent the streamlined creative mode of twentieth century art. Beauty has been found in simplicity. Lack of skilled inlay craftsmen in Pakistan was a major reason for the simple designs. The art is alive today in inlaid furniture, decorative boxes, table tops and marble slabs, etc. but the quality is poor. Ivory is usually fitted in wood rather than precious or semi-precious stones. And beautiful floral patterns are inlaid carefully. The drilling is done by bladed rods, electric drills, chisels and electric grinders.

An octagonal star with eight leaves surrounding each star is the major design on the floor of the fountain in the Faisal Mosque. The golden metallic strips on the white marble surface have a distinctly traditional Islamic flavored. Each leave is an eight-sided shape. The same pattern is repeated individually eight times. Octagonal stars are not new in the history of mosque decoration. They are commonly used for the decorations of the religious buildings of the Muslims. Papdopoulo writes,

"the satellate octagon probably first appeared in Muslim art in the Dome of the Rock, but this was only the start of its great fortune, polygons being the basis of all Islamic abstract rectilinear art" [19].

Octagonal stars were also used on Byzantine surface decorations. The shape achieved a classical character in the ornamentation of Muslim buildings and has been widely used as an architectural decorative pattern by countries previously a part of the Ottoman, Safavid and Mughal empires. In Kashan octagonal shape polychrome tiles were used to cover the wall surfaces. During the Mughal period they were use for floor patterns, with octagonal star, found on the marble floor of the mausoleum of Jahangir, Lahore, Akbar`s tomb at Sikandra and the Diwan-i Khas at Delhi Fort [20].In the Faisal Mosque the use of octagons and octagonal stars are represent continuity with traditional Muslim architectural designs.

Straight-lined geometrical characteristics are preferred for its design composition. Usually inlaid decoration of the Mughal monuments is based on twisted leaves and bold flowers. Its inlaid borders are 
composed of highly stylized patterns of curves and twists with different tints of stones but abstract geometrical designs also have an importance. The façade of Badshahi Mosque shows good examples of geometrical designs in inlay work, where curves are presented with straight lined geometry. But it is not similar with the inlay work of the Faisal Mosque. In the Faisal Mosque decorative designs are planned according to the principles of strict linear geometry. Octagonal stars and flowers are designed with linear edges of geometrical cuts instead of curved floral design. The use of inlay at the Faisal Mosque is unusual for this region. Inlay of metal on white marble surface is not found in the architectural history of the South Asia. It is the personal creativity of the architect who has arranged these materials in simple lines. The entire design of the fountain is based on strict straight-lined geometry in structural form and on surface decoration.

\section{Kurs $\square$}

A kursī is a seat and a desk for Qur'ân readers normally used during the Friday service. In the Faisal Mosque, a kursī entirely constructed of white Thassos marble, is built on the south side of the sanctuary to the left of the mihrāab. It is an octagonal structure eight feet six inches in diameter and three feet, ten inches high "Fig.5". A sitting area is formed with seven boundary walls with the eighth side left open. The walls are topped by a railing six inches thick and five inches high. The outer surface of the kursi is decorated with inlay work on five sides with twelve-pointed golden metallic star shapes "Fig. 6". They are all similar in design, and every one is two feet seven inches in length and two feet five inches wide. Linear designs in metallic strips were cut and embedded in the marble. The execution of the inlay decoration is similar with the inlay work of the marble fountain as discussed in the preceding part of the paper, but the design on the kursī is different. It is based on interlocking triangles each with a double outline. The name of Allah is in muthanna (reflected mirror) style is in the center of the composition [21].The height of the name of Allah is one foot, two inches and its width is eleven inches "Fig. 7". The outer edge of each equilateral triangle is six inches on a side. Metallic strips for the triangular designs are four sixteenth of an inch wide and the strips for the name of Allah are seven eighth of an inch wide.

Karasī were used in mosques from the early days of Islam. Generally there is only one in a mosque but there can be several. In the Faisal Mosque the kursī is built in the sanctuary. In earlier periods it was a freestanding piece of furniture with a seat and a small table for the Qur'ān commonly made in wood. In the Faisal Mosque the kursi is made entirely of white marble. The selection of white marble supports the harmonious colour of the sanctuary as a whole. Its raised octagonal floor is itself used as a seat, where the reader sits and the Qur'ān is placed on rahl (Qur'ān stand). While other inlaid karasi are known that are made of stone and marble, the use of metal inlay in relief form is a new modern concept.

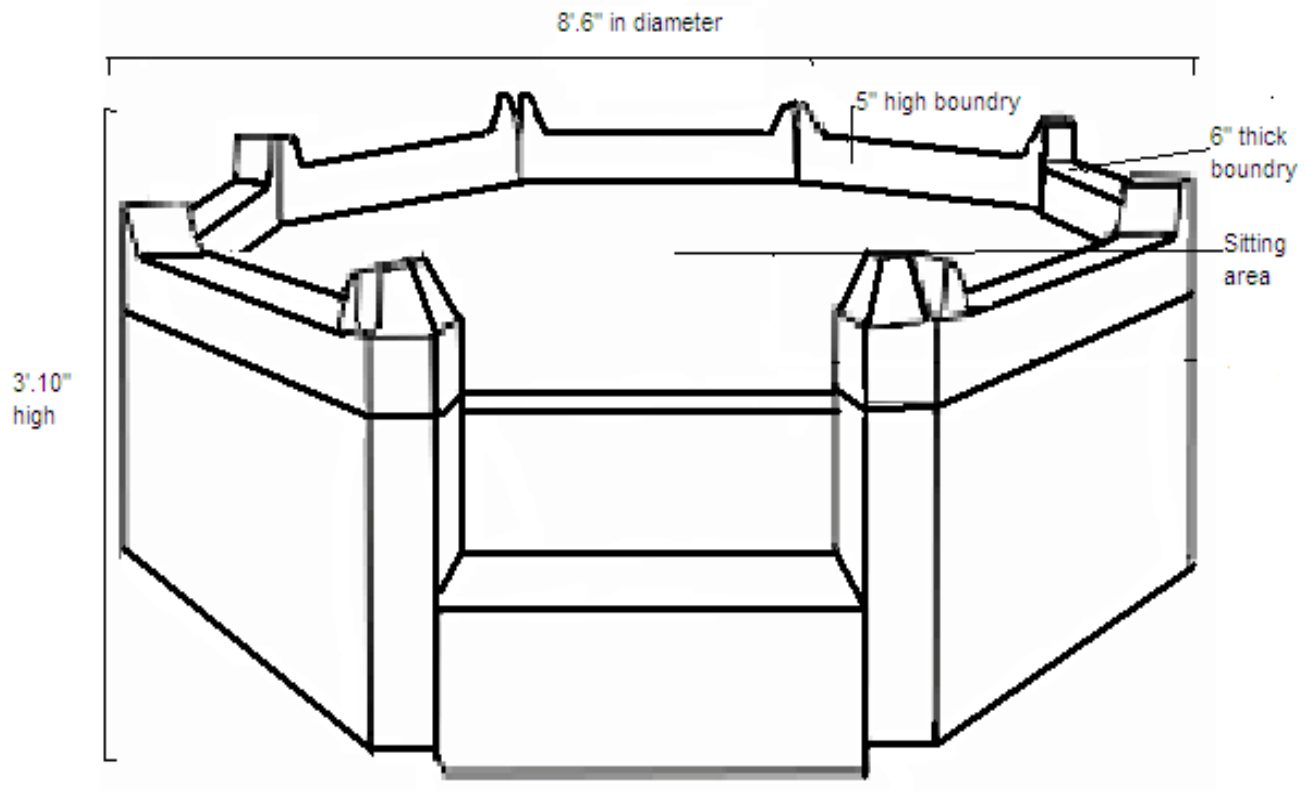

Fig 5. Kursī in the sanctuary of the Faisal Mosque. 


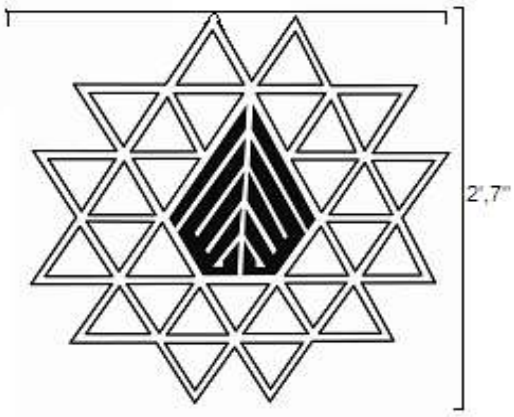

Fig 6. Twelve pointed star on the kursī.

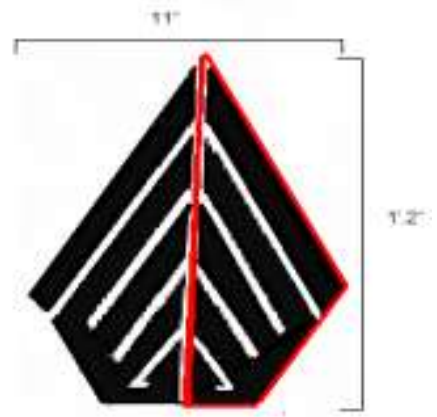

Fig 7. The name of Allah in muthanna style.

In the architecture of the South Asia, the Badshahi Mosque of Lahore, built in 1673 A.D, has inlay decoration in relief and flat form. Its surface decoration is white marble inlaid on red sand stone in low relief and in flat devices. Muhammad 'Abdullah Chughtai has described the decoration of Badshahi Mosque,

"these decorative panels are artistically arranged with flat inlaid margins in strips of white marble.... arabesque are cut out of white marble and inlaid on the red-stone in low relief. i.e. embossed..... this decorative scroll with its pietra dura technique and decorative motifs in an embossed device is hardly found anywhere in subcontinent" [22].

The design on the Faisal Mosque kursi is composed of double triangles and these triangles form a design of twelve-pointed star. Papdopoulo writes about hexagons that they were constructed with two triangles intersecting in opposite directions inscribed in a circle [23]. This design is called the star of David by the Jews and Solomon's seal by the Arabs. It is equivalent to the Hindu mandala known as Yantra, a similar composition of triangles within a circle that has a profound symbolic meaning [24].Rowena and Rupert Shepherd mention that in Hinduism and Buddhism a Yantra is considered as a visual expression of prayer. It symbolizes the forces, power, qualities of various deities and certain cosmic concepts [25].R. Nath reproduces a Tantric symbol called Sri-Yantra based on three main elements: an outer square frame, an arrangement of circles containing stylized lotus flowers and a center design of nine triangles creating a fourteen-pointed star [26].The central part of this symbol is somewhat similar with the star design of kursī in the Faisal Mosque.

On the kursī, the stylized name of Allah and its reflection appear in the center of a twelve pointed polygonal star has an importance as a center of interest. But the placement of the name is disrespectful, because the seat for the Qur'ān reader is higher than the name of Allah! The name is in muthanna style. Yasin Hamid Safadi writes, "Muthanna or Aynali is the art of mirror writing, in which the unit on the left reflects the unit on the right. This technique is also known as Makus (reflected)" [27].

For both, the fourteen-pointed star of Sri-Yantra and the twelve-pointed star of the kursī, straight lines characteristically are found on the entire composition. But in the historical perspective of inlay decoration in South Asia, the interior designs were very minute delicate and giving a luxurious effect. These were inspired by nature and naturalistic designs, especially flowers, leaves, buds stems and birds intertwined with geometrical patterns.

Usually inlaid decoration of Mughal monuments is also based on twisted leaves and bold flowers. The inlaid borders are composed of highly stylized pattern of curves and twists with different tints of stones. Abstract geometrical designs also have their own importance. The façade of the Badshahi Mosque is a live example of geometrical and curvilinear designs in inlay work. In the Faisal Mosque decorative designs are planned according to the principles of strict linear geometry. Stars and flowers are designed with linear 
representation of geometrical cuts instead of relax filling of floral design with soft contours. The Inlay of metal on white marble surface is not found in the history of the area. It is the personal creativity of Vedat Dalokeyturkish architect of the Faisal mosque who arranged the design in simple straight lines.

\section{Conclusion}

This research paper presents importance of inlay decoration of mihräb, marble fountain and kursi built in the sanctuary of the Faisal Mosque. The historical background and sources of their features are established.Design elevation of these does not bear resemblance with any historical construction of Pakistanireligious monument. The presence of fountain in the sanctuary is unusual but seen in early Ottoman mosques at Bursa. Octagons and octagonal stars are commonly used in Muslim architectural decorations. In the Faisal Mosque use of octagons and octagonal stars are presenting continuity of Muslim architectural trends. The importance of rectilinear geometry of the inlay work of fountain and kursi is involved for their decoration. Thetechnique shows their technicality with aesthetic approach through calligraphy and geometrical patterns. Careful study and minute observation leads to the conclusion that many characteristics of geometrical designs in structural form and on the surface of these elements have been inspired by prototypes from throughout the Islamic lands the Faisal Mosque is trend a modern international symbol of Islam. Inlay decoration used in this mosque is revival of Mughal tradition.

\section{References}

[1] Earnst J.Grube, The world of Islam (New York and Toronto, McGraw Hill, 1966).

[2] Richatd G.Tansey and Fred S.Kleiner, Gardner's art through the ages, $10^{\text {th }}$ ed. (New York, Harcourt Brace CollegePublisher, 1996).

[3] Ibid.

[4] Renata Holod, and Hasan-Uddin Khan, The mosque and modern world (London, Thames and Hudson, 1997).

[5] Martin Frishman and Hasan-Uddin Khan, eds. The mosque (London, Thames and Hudson, 1994).

[6] Godfry Goodwin, History of Ottoman architecture (London, Thames and Hudson, 1971).

[7] Ibid.

[8] Andrew, Petersen, Dictionary of Islamic architecture (London and NewYork, Routledge 1996).

[9] George Michell, ed., Architecture of Islamic world (London, Thames and Hudson, 1978).

[10] R. Nath, Agra and its monumental glory (Bombay, Tarporevala Sons, 1977).

[11] Ibid.

[12] Michell, Architecture of Islamic world(London, Thames and Hudson, 1978).

[13] R.Nath, Agra and its monumental glory(Bombay, Tarporevala Sons, 1977).

[14] Ahmad Nabi Khan, Islamic architecture of South Asia (New York, Oxford University Press, 2003).

[15] Ibid.

[16] Ahmad Nabi Khan, Development of mosque architecture in Pakistan (Islamabad, Lok Virsa Publishing House, 1991).

[17] Ebba Koch, Shah Jahan and Orpheus(Graz, Akademische Druck-Verlagsanstalt, 1988).

[18] R. Nath, Color and decoration in Mughal architecture in India and Pakistan (Jaipur, The Historical Research Documentation Program Jaipur, 1989)

[19] Alexandre Papadopoulo, Islam and Muslim art (London, Thames and Hudson, 1980).

[20] R. Nath, Some Aspects of Mughal Architecture (New Delhi, Abhinav Publication, 1976); Mohamed Amin, Duncan Willetts, Lahore (Lahore, Rawalpindi, Karachi: Ferozsons, 1988);Ahmad Nabi Khan, Islamic architecture in South Asia (New York, Oxford University Press, 2003).

[21] In muthanna style the word is written in the form of mirror reflection, means one word is in proper writing way and the other one is in reverse form like mirror reflection.

[22] M. Abdullah Chughtai, The Badshahi masjid (Lahore, Kitab Khana-i-Nauras Urdu Bazar, 1972).

[23] Alexandre Papadopoulo, Islam and Muslim art (London, Thames and Hudson, 1980).

[24] Ibid.

[25] Rowena and Rupert Shepherd, 1000 Symbols (New York, Thames and Hudson, 2002).

[26] R. Nath, Some Aspects of Mughal Architecture (New Delhi, Abhinav Publication, 1976).

[27] Yasin Hamid Safadi, Islamic calligraphy (London, Thames and Hudson, 1978). 